\title{
Legal Constraints on the Enforcement of Covid-19 Health Protocol in Indonesia
}

\author{
Husni $^{1}$, Mahdi Syahbandir ${ }^{2}$, Muhammad Ya'kub Aiyub Kadir ${ }^{3}$, Teuku Ahmad Dadek ${ }^{4}$ \\ ${ }^{1}$ Senior Lecturer Faculty of Law Syiah Kuala University, ${ }^{2,3}$ Lecturer Faculty of Law, Syiah Kuala University, \\ ${ }^{4}$ Student Faculty of Law Syiah Kuala University, Aceh, Indonesia, Mahasiswa Doktoral Ilmu Hukum Universitas \\ Syiah Kuala (Banda Aceh, Indonesia)
}

\begin{abstract}
The positive number of Covid-19 in Indonesia continues to increase and there are no signs of decreasing. This increase was triggered by the implementation of the new normal, long holidays and uncontrolled crowds. And none of this is accompanied by enforcement of health protocol laws (wearing masks, washing hands, maintaining distance and not crowding). This paper examines the legal constraints of enforcing health protocols with normative legal method through library research. The results of his research show firstly, the absence of positive laws that can be used as the basis for law enforcement of health protocols, causing bias in its implementation and health protocols regulated by the Minister of Health Regulation which is not part of the source of positive Indonesian law. Second, the recently issued legal regulations to regulate the enforcement of health protocols are not in accordance with the legal hierarchy prevailing in the Indonesian legal system. Third, specifically for crowd management, the police did not use their authority in accordance with the Criminal Code because it was not prepared to control the Covid-19 crowd, causing multiple interpretations and becoming polemic in the political realm. This study suggests that the Government of Indonesia enact a Government Regulation in Lieu of a Law on Health Protocol Enforcement and provide additional authority to regional heads (governors and regents/mayors) in determining disaster emergencies to also issue regional head regulations in lieu of regional regulations and so that district governments/city and province to propose regent/mayor and governor regulations to become regional regulations that get parliamentary approval.
\end{abstract}

Keywords: Positive Covid-19, Legal constraints, Health protocol.

\section{Introduction}

Introduction from March 2 to 10, December, 2020 positive cases in Indonesia had reached 592,900 people, 487,445 (82.2\%) confirmed cured, 18,171 (3.1\%) people died, the rest received hospital care and independent isolation on the spot, non hospital ${ }^{1}$. This increase occurred due to three factors. First, it was triggered by the Indonesian Government's policy that announced a new normal on July 1, 2020 without a strong legal certainty

\footnotetext{
Corresponding Author:

Teuku Ahmad Dadek

Student Faculty of Law Syiah Kuala University, Aceh, Indonesia

e-mail: tadadek@gmail.com
}

and legal relief approach in enforcing the Covid-19 health protocol. Across Indonesia, the new normal is interpreted as saying that Covid-19 has ended, which is shown by busy going to vacation spots, the culture of going home to a sharp increase, and many wedding parties are being held again. Second, during the Eid alAdha holiday period on July 31, 2020, which runs from July 30 to August 2, 2020 and the long holiday from October 28 to November 1, 2020, where the government increases the holiday period for two days so that the holiday becomes four days ${ }^{2}$.

This Eid al-Adha holiday triggered population mobility (going home) and returning home so that there was community contact with the local community and led to local transmission and it was proven that 15 days later the Covid 19 number had increased sharply and this was also not accompanied by strict enforcement 
of health protocol laws. and monitoring population mobility. The government is considered weak in controlling the mobility of people, which is the easiest route for the spread of the Covid-19 virus. In fact, there are many studies that prove that controlling people's mobility through transportation modes is very essential in the spread of Covid- $19^{3}$.

Third, the police did not use their authority seriously against Article 281 KHUP to disperse the crowd. The latest is the return of Habib Rizieq Shibab, chairman of the Islamic Liberation Front (FPI) who was picked up at Soekarno-Hatta Airport by nearly 50,000 people where the police could do nothing to disperse the crowd.

Health protocol enforcement can be carried out in two ways, namely socialization and law enforcement with imprisonment and fines. The Indonesian government is still taking socialization steps through printed media content, social media, distributing masks, and other activities. However, the number of Covid 19 continues to increase, this indicates that the socialization that was delivered to residents did not go according to expectations, in fact it was said that almost 70 percent of residents ignored this health protocol ${ }^{4}$.

Health protocol law enforcement based on definite and legal formal laws has not been implemented in a structured and systematic manner. This problem not only arises in areas that have not implemented LargeScale Social Restrictions (PSBB), but also occurs in areas that are implementing PSBB, such as the Special Capital Region (DKI), Jakarta. Therefore, the Provincial Government of the Special Capital Region of Jakarta has proposed and ratified that the governor regulation (Pergub) be upgraded to a regional regulation (perda), because it is in accordance with the legal hierarchy in Indonesia $^{5}$.

The Indonesian government strives to provide the meaning of legal certainty and legal legality for state officials that the health protocol can be enforced on a positive legal basis by issuing Presidential Instruction Number 6 of 2020 concerning Improved Discipline and Law Enforcement of Health Protocols in the Prevention and Control of Covid-19 which published on August 4, 2020 as an effort to provide legal certainty in health protocol law enforcement. The absence of legal regulations that are used as the basis for law enforcement is not yet available, causing a gray area, especially the uncertainty of legal regulations governing them, who is the implementer of the law, and how is the procedural law $^{5}$

Then, this condition is exacerbated by the lack of public awareness to comply with health protocols, not to mention that there is distrust that Covid-19 does exist and is attacking. Head of the National Disaster Management Agency (BNPB), Doni Monardo, said that 44 million or $17 \%$ of Indonesia's population does not believe that Covid-19 exists ${ }^{6}$. Carter said that the law has an important influence on disasters, namely 1) as a formal basis for disaster management, 2) allocating and distributing the responsibilities and roles of each party legally, 3) providing national guidance, 4) providing adequate support. it makes sense for reasonable measures such as regulations for provision of funds, 5) provides broad and definite benchmarks, and 6) minimizes legal conflicts, especially in the course of an emergency. ${ }^{7}$

The real and real legal relations to disaster management are: 1) the law strengthens the government's obligations in disaster management; 2) engineering the community to have a culture of disaster awareness; and 3) law formulates mechanisms, organization, participation and international relations. Disaster law is inseparable from the government's disaster law politics. Dadek et al. has defined the politics of disaster law as, "As the government's legal options to enforce or not enforce legal regulations in disaster affairs to protect citizens in order to obtain their rights in disaster risk reduction, in emergencies, as well as to secure rehabilitation and reconstruction guarantees for their lives, as well as regulate all obligations.

Community elements in disaster management, and regulating legal mechanisms between institutions and the community in the pre-disaster, emergency, and rehabilitation and reconstruction processes. "Therefore, as a preventive measure so that it can be measured and has legal certainty to break the Covid-19 chain, as a rule of law, Indonesia must compile a health protocol in the form of legal regulation. ${ }^{9}$ The Indonesian government faces legal obstacles in enforcing the Covid-19 health protocol because existing legal regulations cannot provide a solid basis for enforcing health protocols. Meanwhile, regulations specifically made to punish health protocols do not comply with the hierarchy of legal products in Indonesia. Then, the enforcement of health protocols through health promotion faces obstacles, such as there are still people who think that Covid-19 does not exist and is just a conspiracy, in addition to rejection based 
on the Islamic view that death and the fate of humans have been determined by Almighty God. In fact, there is a hadith of the prophet which states that "if a country is stricken with a plague, then do not go out of the country and into that country." The leader of the DayahDarul Mujahidin Aceh Utara, Tgk Muslim At-Thahiry asked Dayah Dayah in Aceh to refuse the distribution of masks from the Aceh Government. ${ }^{10}$

\section{Materials and Method}

The specification of this research is normative legal research that seeks to describe the legal structure and strength of legal sanctions and to analyze secondary data on the enforcement of Indonesia's Covid-19 health protocol. Sources of data in this study were obtained from literature studies and literature material studied in the form of statutory provisions, expert views, and related research results as well as current case developments. Literature review is carried out by examining legal materials (primary, secondary and tertiary legal materials) both in physical and electronic form. Data collected from library and field research were analyzed using legal and conceptual approaches. The regulatory approach is carried out on research results that have been regulated in statutory provisions, while the conceptual approach is carried out on research results that have not been regulated in statutory provisions.

\section{Results and Discussion}

Lack of Positive Law: Why is law enforcement of Indonesia's Covid-19 health protocol experiencing problems? One of the reasons is the unavailability of positive laws at the level of laws that specifically regulate health protocols (wearing masks, washing hands, maintaining distance and not crowding). While many health protocols are contained in the Decree or Regulation of the Minister of Health, and many health protocols are not only wearing masks, washing hands and maintaining distance, but also how to sneeze, change clothes at home and so on ${ }^{11}$.

In the Indonesian disaster management subsystem that is related to Covid-19, there are various laws such as; Law Number 24 of 2007 concerning Disaster Management (UUPB) as the main regulation, Law Number 23 of 2014 concerning Regional Government (UUPD) also regulates disaster issues, especially covering disaster-prone areas (Article 36), filing regulations in natural disasters (Article 239), emergency funds (Article 296), and division of authority in disaster management between the central, provincial and district/ city levels (attachment), Law Number 23 Year 1992 concerning Health (UUK) which regulates disasters, especially regarding infectious diseases (Articles 28, 29, and 30) and epidemics (Article 31), Law of the Republic of Indonesia Number 4 of 1984 concerning Communicable Disease Outbreaks (UUW) which regulates outbreak areas, countermeasures, rights and obligations, as well as criminal provisions, Law of the Republic of Indonesia Number 6 of 2018 concerning Health Quarantine (UUKK) which regulates quarantine issues, one of which is caused by infectious diseases.

Then, the government also used constitutional authority for "compelling precariousness" by issuing Government Regulation in Lieu of Law (Perpu) of the Republic of Indonesia Number 1 of 2020 concerning State Financial Policy and Financial System Stability for Handling Pandemic Coronavirus Disease 2019 (Covid-19) and/or In the Context of Facing Threats that Endanger the National Economy and/or Financial System Stability which regulates State Finances and Financial Stability. This second group is based on the principle of centralization in handling impacts, health emergency status, quarantine mechanisms, and so on. ${ }^{11}$

In the legal system for disaster management in Indonesia, there has not been a single article that can be used as a legal basis in enforcing the Covid-19 health protocol. However, there are several laws that can be used as a reference in criminal enforcement related to disasters which must be carried out through legal discovery by judges which require a long and long time and mechanism. First, in Law Number 24 of 2007 concerning Disaster Management there are also several criminal provisions and the imposition of fines, both for individuals and legal entities, namely in Articles 75 to 79.

The essence of the penalties of this law are high risk, which is not equipped with disaster risk analysis, b) deliberately hampers easy access during a disaster emergency, and c) deliberately misuses the management of disaster relief resources. Thus, this Disaster Management Law also cannot be used as a reference in enforcing the Covid-19 health protocol as a non-natural disaster in the form of an outbreak. Second, Law of the Republic of Indonesia Number 4 of 1984 concerning Outbreaks of Communicable Diseases which in Article 14 paragraph (1) regulates "punishment for a person who deliberately obstructs the implementation of epidemic 
control, shall be punished with a maximum imprisonment 1 (one) year and/or a maximum fine of Rp. 1,000,000.00 (one million rupiah). "This verse is categorized as evil. Article paragraph (2) stipulates "whoever because of his/ her negligence causes obstruction of the implementation of the prevention of the epidemic, shall be punished with a maximum imprisonment of 6 (six) months and/or a maximum fine of Rp. 500,000.00 (five hundred thousand rupiahs."

This paragraph is categorized as a form of offense. What is meant by efforts to contain an infectious disease outbreak? Government Regulation of the Republic of Indonesia Number 40 of 1991 concerning Prevention of Communicable Disease Outbreaks in Article 10 states that "Efforts to contain epidemics include epidemiological investigations, examinations, treatment, treatment and isolation of sufferers, including quarantine measures, prevention and immunity, eradication of disease causes, handling of corpses. due to the epidemic, public outreach, and other prevention efforts. "Can the word "prevention" in this article legally be applied to those who do not wear masks while traveling outside the home? Or when holding a wedding party? In the explanation of number 13 of Government Regulation Number 40 of 1991 concerning Outbreak Management, it is stated that "What is meant by prevention and immunization are efforts to prevent and immunity people and their environment so that they do not contract the disease. These activities can be done through vaccination, spraying, and others. "

Thus, regulations regarding prevention by wearing masks, washing hands, and maintaining a distance cannot be fined by this article. This is because this article by law does not directly regulate the obligation to wear a mask and maintain a distance. A violation rule cannot be imposed on them without a clear legal basis regulating it in the law. Third, Law Number 23 Year 1992 concerning Health regulates criminal provisions in the terms of crime (Articles 80, 81, and 82) and offenses (Article 84).

Article 80 paragraph (1) regarding illegal medical actions, Article 82 concerning conducting illegal treatment and/or treatment, and illegal pharmaceutical actions, Article 84 crimes in circulating food and or drinks that are not marked or labeled and operating workplaces that do not meet standards, prevent people with mental disorders who will be treated and/or treated at health service facilities, from operating health facilities that do not meet the requirements. The Health Law also cannot be used as a basis for enforcement of health protocols during the Covid-19 pandemic. Fourth, Law of the Republic of Indonesia Number 6 of 2018 concerning Health Quarantine in which Article 93 regulates non-compliance with the administration of health quarantine and/or obstructs the administration of health quarantine so as to cause a public health emergency to be punished with imprisonment of up to 1 (one) year and/or a maximum fine of Rp 100,000,000.00 (one hundred million rupiah).

Fifth, Perpu No.1/2020 which regulates the issue of health impacts on the economy. Supposedly, the government should not only contain financial matters for handling health, economic impacts, and social safety net, but also regulate legal matters of health protocol enforcement. Because there is no positive law regulating the enforcement of health protocols (wearing masks, washing hands and keeping your distance) which does not have legal certainty and based on the principle of legality, first, the government and its law enforcement officers are only able to enforce health protocols with social sanctions, not law. like singing clean the way to read the Koran. ${ }^{12-14}$

Second, the State, in this case represented by the President, still considers that the legal rules regarding the prevention of infectious disease outbreaks are not yet available in articles in the legal regulations that contain health protocols and cannot be implemented. This is evidenced by the issuance of Presidential Instruction Number 6 of 2020 concerning Increasing Discipline and Law Enforcement of Health Protocols in the Prevention and Control of Covid-19 which was issued on August 4, 2020 which aims to provide legal certainty and encourage regions to issue regional head regulations that contain legal sanctions.

Violations of Health Protocols: Third, there is a legal polemic in enforcing health protocols regarding which articles are most appropriate to be used in apprehending health protocol violators, as we will discuss in the case of Habib Rizieq Shihab, the High Imam of the Isla Defenders Front. Fourth, law enforcement changes to a political discourse so that health protocol enforcement is in an area where there is no legal certainty so that the authority is unclear between the central and regional governments. Contrary to the Legal Hierakis to provide legal certainty in enforcing health protocols legally, President Joko Widodo issued Presidential Instruction Number 6 of 2020 concerning Increasing Discipline and Law Enforcement of Health Protocols in the Prevention 
and Control of Covid-19 as an effort to enforce the law by providing sanctions in the form of legal fines on August 4, 2020. In the first dictum the presidential instruction (inpres) stipulates that, "The Ministers of the Advanced Indonesian Cabinet, the Cabinet Secretary, the Commander of the Indonesian National Army, the Chief of the Indonesian National Police, the heads of non-ministerial government agencies, the governors and regents/mayors take steps -the steps needed are in accordance with their respective duties, functions and authorities in ensuring legal certainty, strengthening efforts and increasing the effectiveness of the prevention and control of Coronavirus Disease 2019 (Covid-I9) in all provinces and districts/cities in Indonesia. "This Presidential Instruction also instructs regional heads to issue regional head regulations to contain sanctions in the form of: verbal warning or written warning, social work, administrative fines, or termination or temporary closure of business operations, whereas from the legal hierarchy point of view, regional head regulations are not justified. loading sanctions.

In the second dictum point 6 letter $\mathrm{b}$ of the presidential instruction, it states that the governor/regent/ mayor drafts a governor regulation or regent/mayor regulation by including sanctions for violations of the Covid-19 Protocol committed by individuals, business actors, managers, organizers, or person in charge of public places and facilities. This Presidential Instruction includes a legal flaw in terms of both the legal hierarchy and the regulated material. First, the Inpres is not part of the hierarchy of legislation in Indonesia, but is part of what Ishviati Joenaini Koenti says is a complement to the principle of legality and is a form of discretion. This is due to the limitations and weaknesses of written law, namely: it is impossible for the law to be complete because of the complexity of society's problems and written regulations are static. Discretion is something that cannot be avoided, both for the application of law itself and in the implementation of government. ${ }^{15}$

Presidential Instruction Number 6 of 2020 contradicts Article 7 paragraph (1) of Law Number 15 of 2019 concerning Amendments to Law Number 12 of 2011 which has regulated the hierarchy of statutory regulations, in which presidential instructions and governor regulations, as well as regent regulations/ mayor is not included in the hierarchy of the laws and regulations of the Republic of Indonesia. Second, based on this instruction, the Indonesian government issued regional head regulations, one of which is what the Aceh
Government implemented by issuing Aceh Governor Regulation Number 51 of 2020 concerning Improved Handling of Coronavirus Disease 2019 Implementation of Discipline and Law Enforcement of Health Protocols in Aceh on 7 September 2020. ${ }^{16}$

The regulation of the legal material for sanctions in the head regulation is contrary to Article 15 paragraph (1) which states that the contents of the criminal provisions can only be contained in: a. Constitution; $b$. provincial regional regulations; or c. district/city regional regulations. Meanwhile, the Presidential Instruction and Aceh Governor Regulations, as well as regent/ mayor regulations are not laws and are not regional regulations and are contrary to Article 15 paragraph (3) which states that provincial regional regulations and district/city regional regulations can contain the threat of imprisonment or imprisonment. criminal fine. Regulations by governors and regents/mayors are not legal products that are justified in imposing sanctions in any form.

"The statutory regulations in the Republic of Indonesia consist of: a) The 1945 Constitution of the Republic of Indonesia, b) Decrees of the People's Consultative Assembly, c) Laws/government regulations in lieu of laws, d) Government regulations, e) Presidential regulations, f) Provincial regulations, and g) District/city regulations. "Whereas Article 14 of the law states, "the material contained in Provincial Regulations and Regency/City Regulations contains material in the framework of implementing regional autonomy and co-administration, as well as accommodating special regional conditions and/or further elaboration of higher laws and regulations. "Regarding crimes, Article 15 paragraph (1) states that "The contents of criminal provisions can only be contained in 1) Laws, 2) Provincial Regulations, 3) Regency/City Regulations." The criminal threat is "imprisonment for a maximum of 6 (six) months or a maximum fine of Rp.50,000,000.00 (fifty million rupiah)." Paragraph (2) regulates, "Provincial Regulations and Regency/City Regulations may contain the threat of imprisonment or fines other than those stipulated in other statutory regulations." However, the Presidential Instruction and the Aceh Governor Regulation are not laws, nor are they provincial regulations and district/city regional regulations, but are merely instructions and governor regulations that cannot contain sanctions. ${ }^{17,18}$ 


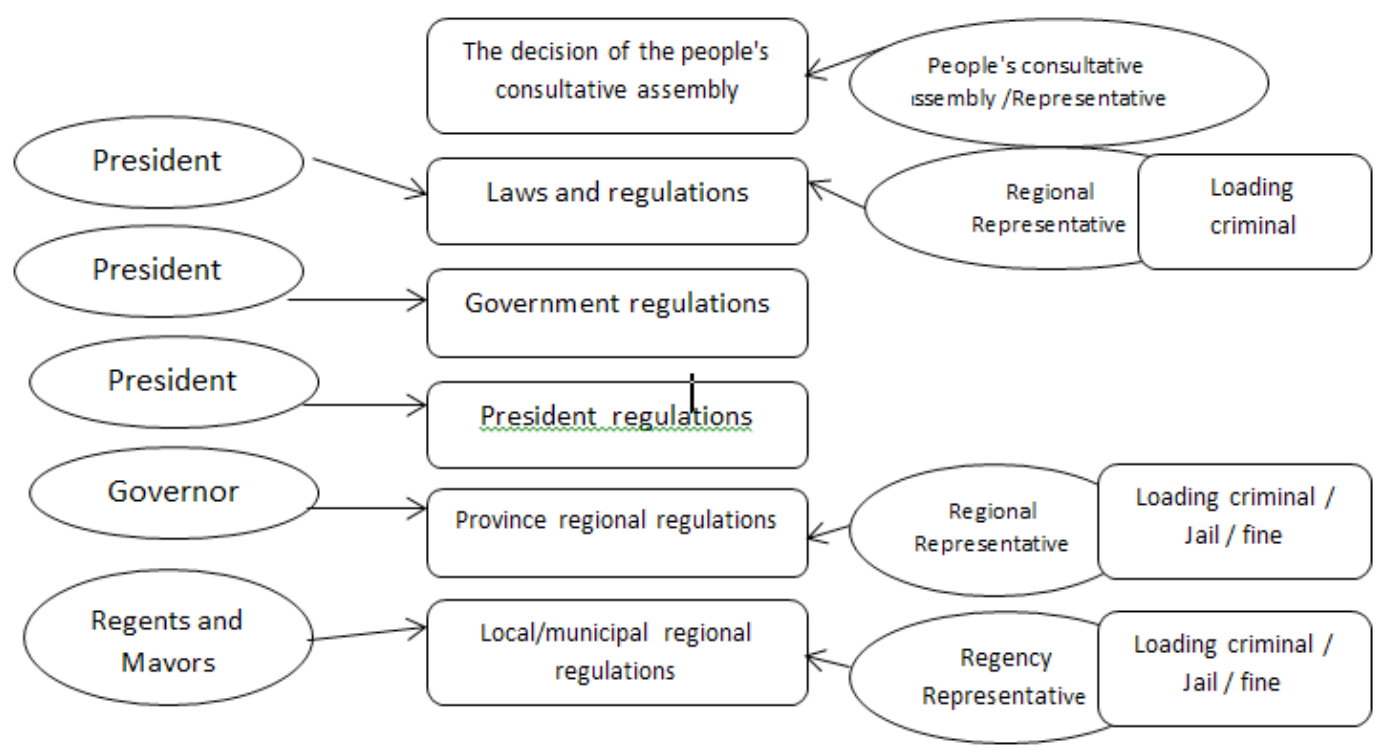

Figure 1. Hierarchical Indonesian Legislations

In Indonesia, a hierarchy of regulations has been regulated even though normatively it also adheres to unwritten customary law, but most legal cases decided by official Indonesian courts are based on written legal regulations issued or issued by state institutions. This means that Indonesia strictly adheres to the principle of legality, that is, all legal decisions based on regulations issued by government agencies in accordance with the authorities granted by law. The principle of legality is applied in criminal law. ${ }^{19}$

Article 1 paragraph (1) of the Criminal Code affirms that an act cannot be punished, except based on the strength of the existing criminal legislation. Anselm Von Feuerbach called it the principle of legality with the adage Nullumdelictumnullapoenasinepravialegepoenali. The principle of legality actually exists in the realm of State Administrative Law, which is a principle in which every administrative act must be based on law, both in making regulations and in stipulating and enforcing them. Indonesia strictly adheres to the principle of legality, that is, all legal decisions based on regulations issued by government agencies ${ }^{20}$.

The law demands legality, what is required is the implementation and obedience or the actions that are required on an obligatory basis. There are two principles that must be adhered to in the legal system, especially those that contain sanctions against society. First, the principle of legal certainty and the principle of legal legality, as well as the principle of democracy. Any imposition on the community must be carried out with valid legal rules, the rules of which are discussed jointly between the executive and legislative branches, both at the level of the formation of laws, as well as the formation of provincial and district/city regional regulations ${ }^{21}$.

Crowd Disbandment One of the weaknesses of the Indonesian Government in deciding the spread of Covid-19 is the uncontrolled crowd. This is because first, the concept of generality in the Covid-19 context is different from the concept of generality as regulated in the Criminal Code. Second, the legal concept in the Criminal Code crowd was not prepared for the concept of generality in the Covid-19 context. Third, many health protocol settings are regulated in the minister of health regulations which are not part of the structure of positive sources of law in Indonesia. What differentiates the crowd in the Covid-19 context from the crowd in the Criminal Code? What is clear is that the generality in the Criminal Code is planned, structured and there are political elements in society voicing their interests (common interests of groups), while the concept of crowds in the Covid-19 context is spontaneous, uncoordinated and just a coincidence. Examples of crowd demonstrations and crowds of people in public places such as to markets, stations and so on. ${ }^{23}$

Therefore the Chief of Police of the Republic of Indonesia tried to attract and provide a legal definition so that the crowd in the Criminal Code can be interpreted as a crowd in the context of terminating the spread of 
Covid-19. The announcement of the Chief of Police of the Republic of Indonesia Number: Mak/2/III/2020 concerning Compliance with Government Policy in Handling the Spread of the Corona Virus contains the first, "the principle of people's safety is the highest law (Solus Populi Suprema Lex Esto)", second, "do not hold social activities social gatherings that lead to mass gathering in large numbers, both in public places and in their own environment, such as 1) social, cultural, religious and religious gatherings in the form of seminars, workshops, gatherings, and other similar activities; 2) activities of music concerts, fairs, festivals, bazaars, night markets, exhibitions and family reception; 3 ) sports activities, arts and entertainment services; 4) demonstrations, parades, carnivals; and 5) other activities that bring together the masses.

"This announcement also provides another bias to the public that in "urgent circumstances it cannot be avoided, activities that involve many people are carried out by maintaining a constant distance and must follow government procedures related to preventing the spread of Covid-19." This announcement is published on March 19, 2020. When crowds are allowed in Pilkada, the government has taken two different policies, even though one party crowd is protected by law, but when it applies during a pandemic, the crowd should not be enforced even with strict health protocols, because in fact every crowd in Indonesia health protocols are always being violated, especially wearing a mask and keeping your distance. This edict also cannot be used as a reference for positive law for two reasons. First, the announcement of the Chief of Police of the Republic of Indonesia is not positive law in the statutory system which is the basis of legal law in Indonesia. This regulation is only binding for the internal police, which is usually used to set internal operational standards for the police. Second, in content, the proclamation reopens the opportunity that crowds can be exercised for reasons of unavoidable interest, by not providing a legal definition of any "unavoidable circumstances".

Meanwhile, crowd dispersal has been regulated in Article 218 of the Criminal Code (KUHP), but it is not used optimally by the police because this article has multiple interpretations and is indeed formed to control crowds related to demonstrations and is political in nature, and the legal sanctions are only dissolution only. First, the use of Articles 212, 216, and 218 of the Criminal Code which can be used as an ultimatum remedium in enforcing health protocol laws. Article 212 of this law states that "Anyone with violence or threats of violence against an official who is carrying out a legitimate task, or who according to statutory obligations or at the request of the official to provide assistance to him, is threatened for fighting an official, with imprisonment. a maximum of one year and four months or a maximum fine of four thousand five hundred rupiahs. "

This article cannot be used as a basis for enforcement of the health protocol law, considering that this article contains elements of "violence" or "threats of violence" with the intention of "fighting" an "official" or "person providing help". Meanwhile, not wearing a mask, not keeping your distance is not an act of threatening violence or not fulfilling the elements of the article. Although legal discovery efforts can be carried out, such discovery activities in the criminal law system must adhere to the principle of legality. Article 216 paragraph (1) stipulates; "Anyone who deliberately does not obey orders or requests made according to law by an official whose job is to supervise something, or by an official based on his duties, as well as those who are authorized to investigate or examine a criminal act; Likewise, any person who deliberately prevents, obstructs or thwarts action to enforce the provisions of the law by one of these officials, shall be punished by a maximum imprisonment of four months and two weeks or a maximum fine of nine thousand rupiahs. (2) Equal to the aforementioned criminal, any person who according to the provisions of law has been continuously or temporarily assigned the task of carrying out a public office."

This article also cannot be used as a basis for fines and penalties, considering that there must be an "order" or "request" which must also be based on law. As is well known, there is not a single article in the law in Indonesia that contains articles that are clear about wearing masks, washing hands and keeping your distance. Article 218 stipulates, "Anyone who, when the people arrive in a crowd, deliberately does not leave immediately after being ordered three times by or on behalf of the competent authority, is threatened with participating in a grouping by a maximum imprisonment of four months and two weeks or a maximum fine of nine thousand. Rupiah".

Article 218 also cannot be used as an attempt to convict a person or group of people who are gathering because it is not a crowd dealing with demonstrations or the like, but crowds because the factors of the epidemic are very different. Crowds like this are very common 
in crowded centers. On what basis can the police use this article? In positive law in Indonesia, the matter of this crowd can be found in Article 216 and Article 218 of the Criminal Code. Article 216 paragraph (1) reads, "Whoever deliberately does not comply with orders or requests made according to law by an official whose job is to supervise something, or by an official based on his duties, as well as those who are authorized to investigate or examine a criminal act; Likewise, any person who deliberately prevents, obstructs or thwarts action to enforce the provisions of the law by one of these officials, shall be punished by a maximum imprisonment of four months and two weeks or a maximum fine of nine thousand rupiahs. ${ }^{23}$

Whereas Article 218 of the Criminal Code states, "Anyone who when the people come together deliberately does not leave immediately after being ordered three times by or on behalf of the competent authority, is threatened for participating in a grouping with a maximum imprisonment of four months and two weeks or a maximum fine nine thousand rupiah. "This article requires a long enforcement and trial mechanism in the Indonesian legal system and this article is aimed at crowds who are about to hold a demonstration using a mechanism that has been stipulated by law, especially Law Number 9 of 2008 concerning Freedom to Express Opinions in Public. This article was used to charge 27 workers with peaceful expression of opinions on October 30,2015 , on charges of "disrespecting the orders of the authorities recognized by law, namely police officers" and "not dissolving themselves after being warned three times by police officers. "So that on that basis the police officers forcibly dispersed and arrested 23 protesters and three lawyers/assistant public lawyers for LBH Jakarta. ${ }^{24}$

Second, many policies (discretion) are published, but in the Indonesian legal system discretion is not part of a legal product in the hierarchy of the statutory order. One of these discretions is the Minister of Home Affairs Regulation Number, Instruction of the Minister of Home Affairs No. 6 of 2020, Enforcement of the Health Protocol to Control the Spread of Covid-19 which contains the threat of removing regional heads in violation of the law ${ }^{25}$.

This Imendagri letter also caused polemics in the community about the power of law. Third, the legal uncertainty of the program has caused the handling of the crowd during the Covid-19 period to have no legal certainty for its implementation. Fourth, there are differences in legal definitions between the crowd in the context of the law of freedom of expression and the crowd which is not in the context of freedom of opinion such as weddings, commemoration of the Prophet's birthday, and so on. Then, the Minister of Home Affairs also issued the Minister of Home Affairs Instruction No. 6/2020 on the Enforcement of Health Protocols to Control the Spread of Covid-19 which contained the threat of removing regional heads in violation of the law. This Imendagri letter also caused polemics in the community about the power of law. The polemic surrounding the Imendagri is not included in Indonesia's positive law, with the first reason that the process of dismissing regional heads is in accordance with statutory regulations, especially the Regional Government Law (UUPD), regional heads are elected by the people and determined by the General Election Commission (KPU) and the president have no right to refuse. Dismissal must be through the DPRD with an impeachment mechanism until the opportunity to defend oneself to the Supreme Court. Second, based on Law Number 15 of 2019 concerning the Compilation of Legislation, the Presidential Instruction is no longer included as a form of legislation. This is to put an end to doubts about the status of the Inpres that were very much published during President Soeharto.

This inability to apply sanctions and fines resulted in massive demonstrations during the pandemic such as the Omnibus Law demonstration of the Job Creation Act and finally RizieqShihab which resulted in the Head of the Jakarta and Banten Special Capital Region Police being removed from his position and this case has caused polemic laws ranging from criminalizing clerics, violating health protocols violating the Health Law, then Rizieq was detained under other legal regulations that have nothing to do with violating the Covid-19 health protocol but relating to incitement and fighting against the authorities. Finally, there was a shooting which killed six of Rizieq's bodyguards ${ }^{26-31}$.

\section{Conclusion}

Positive law that exists in Indonesia, there are no specific articles that can be applied to enforce health protocols (wearing masks, washing hands, keeping distance, and not crowding) so that implementation has created legal uncertainty and is not in accordance with the principle of legality, and tends to enter in a political versus legal interpretation. The Indonesian government is aware of the legal vacuum and the existence of legal uncertainty which results in the enforcement of health 
protocols into legal polemic and has not been able to become a legal instrument with coercive power to suppress the positive number of Covid-19. The legal vacuum was then addressed by the central government by issuing Presidential Instruction Number 6 of 2020 which essentially wanted to provide legal certainty in terms of enforcing health protocols and the Instruction of the Minister of Home Affairs Number 6 of 2020 dated 18 November 2020 , which essentially contained a threat to regional heads who violated laws and regulations can be dismissed. However, enforcement of health protocols remains a legal polemic, in other words, enforcement does not meet the requirements and legal certainty.

The Minister of Home Affairs has issued Circular Number 440/31660 dated May 15, 2020, which in its third point asks regional heads to prepare regional regulations that contain health protocols. As of November 2020, only DKI Jakarta has made it a regional regulation. There are several solutions that can be taken in solving this problem of legal certainty and so that there is a definite law enforcement. First, in the short term, the Government of Indonesia must immediately issue government regulations in lieu of laws (perppu) for the benefit of systematically enforcing health protocols so that health protocol enforcement has certainty, both material and formal laws, and law enforcement is certain, namely the police, prosecutors., and judiciary (court). Much must be regulated in the Government Regulation in Lieu of a Law, such as the use of Covid-19 patient data by the police, Second, for the short term, the governor and regent/mayor immediately propose to the parliament so that the governor regulations and regent/ mayor regulations can be made into regional regulations/ qanuns so that they have legal certainty in the imposition of fines and other sanctions.

Third, for the long term, the authority to determine disaster emergency status by governors, regents and mayors needs to be expanded, with the governors and regents/mayors being authorized to issue governor/ regent/mayor regulations in lieu of regional regulations. This is analogous to the authority of the president, but governors and regents/mayors are given limits on their authority, namely only for disaster regulations, especially in imposing imprisonment and fines on residents who violate health protocols. Even the Chinese Government, which has tended to rely on the control of the communist political party since the last five years, especially under Xi Jinping, has developed the principle of legal legality, namely a very legalistic way, empowering courts, emphasizing legal professionalism, in other words the principle of legality where no punishment can be imposed, unless there is positive law in writing regulating it. In other words, the Chinese authorities make more use of organizational capacity and legal legitimacy rather than circumventing the legal system.

Ethical Clearance: Taken from the University ethical committee

\section{Source of Funding: Self}

Conflict of Interest: We declare no conflict of interest within this research and publication

\section{References}

1. Badan Nasional Penanggulangan Bencana Indonesia, 'Peta Sebaran', Https://Covid19. Go.Id/, $2020<$ https://covid19.go.id/peta-sebaran> [accessed 10 December 2020].

2. Roels $\mathrm{Ni}$ and others, 'Implementasi Konsep Responsible Tourism Marketing (Rtm) Di Desa Wisata Jatimulyo Kabupaten Kulonprogo Yogyakarta', $18.2 \quad$ (2020) $\quad<$ https://doi. org/10.36275/mws $>$.

3. Muhammad Arfan and others, 'A Caputo Power Law Model Predicting the Spread of the COVID-19 Outbreak in Pakistan', Alexandria Engineering Journal, $\quad 2020<$ https://doi.org/10.1016/j. aej.2020.09.011>.

4. Ihsanuddin, 'Kasus Covid-19 Tembus 300.000, Satgas: Masih Ada Warga Abai Protokol Kesehatan', Kompas.Com, $2020<$ https://nasional. kompas.com/read/2020/10/06/19275801/kasuscovid-19-tembus-300000-satgas-masih-adawarga-abai-protokol-kesehatan $>$ [accessed 11 December 2020].

5. Ryana Aryadita Umasugi, 'Perda Penanganan Covid-19 Disahkan DPRD DKI’, 2020 $<$ ht tps://megapolitan.kompas .com/ $\mathrm{read} / 2020 / 10 / 19 / 15202321 /$ perda-penanganancovid-19-disahkan-dprd-dki> [accessed 29 November 2020].

6. Arief Munandar, 'Doni Monardo: 44,9 Juta Orang Indonesia Tak Percaya Ada Covid-19', Poskota, $2020<$ https://poskota.co.id/2020/10/9/donimonardo-sebut-449-juta-warga-masih-belumpercaya-covid-19> [accessed 29 November 2020].

7. W. Nick. Carter, Disaster Management A Disaster 
Manager's Handbook, Asian Development Bank, $2008<$ https://www.think-asia.org/bitstream/ handle/1 1540/5035/disaster-managementhandbook.pdf? sequence $=1>$.

8. Sulaiman Teuku A Dadek, Yanis Rinaldi, Politik Hukum Bencana Indonesia, I (Banda Aceh: Universitas Syiah Kuaa Banda Aceh, 2020).

9. Anwar Mallongi, Agus Bintara Birawida, and Noer Bahri Noor, 'Study of Covid 19 Occurrence in Relation to Masks and Hand Sanitizers Use', 20.4 (2020), 1175-80.

10. Ilham Pranata, 'Dayah Di Aceh Diminta Tolak Bantuan Masker Dari Pemerintah Aceh', Info Aceh Timur, $2020<$ https://www.infoacehtimur. com/2020/10/dayah-di-aceh-diminta-tolakbantuan.html>.

11. Karni Ilyas, 'Vice Versa! Irmanputra Sidin: Kepala Daerah Bukan Oposisi Presiden, Begitupun Sebaliknya' (Indonesia: TVONE, 2020) <https:// www.youtube.com/watch?v=XZFxYEXPmMI>.

12. Muhajir Arifin, 'Langgar Protokol Kesehatan, 142 Warga Pasuruan Hanya Dihukum Nyanyi', DetikNews, $2020<$ https://news.detik.com/ berita-jawa-timur/d-5127804/langgar-protokolkesehatan-142-warga-pasuruan-hanya-dihukumnyanyi $>$ [accessed 23 November 2020].

13. Eleonora Padmasta Ekaristi Wijana|Muhammad Ilham Baktora, 'Langgar Protokol Kesehatan, 136 Orang Bersihkan Jalanan Di Malioboro', Suarajogja.Go.Id, $2020<$ https://jogja.suara. com/read/2020/09/15/184603/langgar-protokolkesehatan-136-orang-bersihkan-jalanan-dimalioboro $>$ [accessed 23 November 2020].

14. Rep: Antara/Red: Christiyaningsih, 'Langgar Protokol Kesehatan Di Aceh Disanksi Baca Alquran', Republika.Co.Id, $2020<$ https:// republika.co.id/berita/daerah/sumatra/qh1972459/ langgar-protokol-kesehatan-di-aceh-disanksi-bacaalquran> [accessed 23 November 2020].

15. Ishviati Joenaini Koenti, 'Diskresi Dalam Penanggulangan Bencana Di DIY Dengan Paradigma Kontinjensi', Jurnal Hukum IUS QUIA IUSTUM, 23.3 (2016), 461-85<https://doi. org/10.20885/iustum.vol23.iss3.art6>.

16. Pemerintah Aceh, 'Dokumen Dan Informasi Hukum', $2020<$ http://jdih.acehprov.go.id/dih/ detail/b81a0e8c-41d9-4a92-80c4-079492328933> [accessed 29 November 2020].
17. Satjipto Rahardjo, Hukum Dalam Jagat Ketertiban, Pertama (Jakarta: UKI Press, 2006).

18. Peter Mahmud Marzuki, Pengantar Ilmu Hukum, Pertama (Jakarta: Kencana, 2011).

19. Muhammad Bakri, Pengantar Hukum Indonesia Jilid 2: Pembidangan Dan Asas-Asas Hukum (Malang: Universitas Brawijaya Press, 2013). Hal 120

20. Mercedes Pérez Manzano, Juan Antonio Lascuraín Sánchez, and Marina Mínguez Rosique, 'Multilevel Protection of the Principle of Legality in Criminal Law', Multilevel Protection of the Principle of Legality in Criminal Law, 2017, pp. 1-234<https:// doi.org/10.1007/978-3-319-63865-2>.

21. Prajudi Atmo Sudirdjo, Hukum Administrasi Negara (Jakarta: Ghalia Indonesia, 1983).

22. Kadek Melda Luxiana, 'Kapolri Terbitkan Maklumat Kepatuhan Protokol Kesehatan Pilkada 2020', DetikNews, $2020<$ https://news.detik.com/ berita/d-5181773/kapolri-terbitkan-maklumatkepatuhan-protokol-kesehatan-pilkada-2020> [accessed 11 December 2020].

23. Rindi Nuris Velarosdela, 'Ini Ancaman Hukuman Bagi Warga Yang Nekat Berkerumun Saat Ada Wabah Corona', Kompas.Com, $2020<$ https://megapolitan.kompas.com/ $\mathrm{read} / 2020 / 03 / 24 / 11074241 /$ ini-ancamanhukuman-bagi-warga-yang-nekat-berkerumunsaat-ada-wabah $>$ [accessed 11 December 2020].

24. Ahmad Sofian, 'Tafsir Pasal 216 Dan 218 KUHP Dalam Kaitannya Dengan UU NO. 9 TAHUN 1998', $2020<$ https://business-law.binus. ac.id/2016/10/30/tafsir-pasal-216-dan-218-kuhpdalam-kaitannya-dengan-uu-no-9-tahun-1998/> [accessed 29 November 2020].

25. Yusril Ihza Mahendra, 'Presiden Dan Mendagri Tidak Berhak Copot Kepala Daerah, Harus Dari Rakyat', Https://Wartakota.Tribun, $2020<$ https:// wartakota.tribunnews.com/2020/11/20/yusril-ihzamahendra-sebut-presiden-dan-mendagri-tidakberhak-copot-kepala-daerah-harus-dari-rakyat> [accessed 21 November 2020].

26. Dandy Bayu Bramasta, 'Sederet Pejabat Yang Dicopot Karena Disebut Abaikan Protokol Kesehatan', Kompas.Com, $2020<\mathrm{https}$ //www. kompas.com/tren/read/2020/11/24/100500065/ sederet-pejabat-yang-dicopot-karena-disebutabaikan-protokol-kesehatan?page $=$ all $>\quad$ [accessed 
10 December 2020].

27. Matius Alfons, 'Habib Rizieq Tersangka, FPI Sebut Kriminalisasi', DetikNews, $2020<\mathrm{http}$ :// news.detik.com/berita/d-5289616/habibrizieq-tersangka-fpi-sebut-kriminalisasi?utm source=notifikasi \& utm_campaign=browser \& utm_medium $=$ desktop $>$ [accessed 10 December 2020].

28. Tim Redaksi Nusantara, 'Dituduh Langgar Protokol Kesehatan, Satpol PP DKI Denda Habib Rizieq Syihab', Kabarriau, $2020<\mathrm{https}$ //www. kabarriau.com/berita/3777/dituduh-langgarprotokol-kesehatan-satpol-pp-dki-denda-habibrizieq-syihab>.
29. Ctr/nma, 'Pakar Sebut Rizieq Tak Bisa Kena UU Kekarantinaan Kesehatan', Cnnindonesia, 2020.

30. Ivany Atina Arbi, 'Rizieq Shihab Tersangka, Dituduh Lakukan Penghasutan Dan Melawan Aparat', Kompas, $2020<$ https://megapolitan. kompas.com/read/2020/12/10/13531581/rizieqshihab-tersangka-dituduh-lakukan-penghasutandan-melawan-aparat> [accessed 10 December 2020].

31. Erick Tanjung, 'Enam Pengawal Rizieq Ditembak Mati, Polri Persilakan Komnas HAM Bentuk Tim', Suara.Com, $2020<$ https://www.suara.com/ news/2020/12/08/183920/enam-pengawal-rizieqditembak-mati-polri-persilakan-komnas-hambentuk-tim $>$ [accessed 10 December 2020]. 